\title{
Cnidoscolus monicanus (Euphorbiaceae), an Endemic New Species of Laticiferous, Non-Stinging Spurge Nettle from Western Mexico
}

\author{
José Aquileo Lomelí-Sención ${ }^{1}$ and Eduardo Sahagún-Godínez ${ }^{2}$ \\ Jardín Botánico y Herbario, Universidad Autónoma de Guadalajara, Av. Patria 1201, Apartado \\ postal 1-440,44100 Zapopan, Jalisco, México. ㄹedilanthus@yahoo.com.mx; \\ ${ }^{2}$ cladium@yahoo.com.mx
}

Victor W. Steinmann

Instituto de Ecología, A.C., Centro Regional del Bajío, Apartado postal 386, 61600 Pátzcuaro, Michoacán, México. victor.steinmann@inecol.edu.mx

Abstract. Cnidoscolus monicanus J. A. Lomelí, Sahagún \& V. W. Steinmann (Euphorbiaceae), endemic to western Mexico, is described and illustrated. This new species belongs to Cnidoscolus Pohl sect. Calyptrosolen (Müller Argoviensis ex Pax) Pax \& K. Hoffmann and is closely allied to C. elasticus Lundell and $C$. tepiquensis (Costantin \& Gallaud) McVaugh. We provide an identification key to the $C$. tepiquensis complex. These species share an arborescent and little or non-urticating habit at maturity, inflorescences that are often unisexual, and large seeds. We hypothesize that these species constitute a monophyletic group within section Calyptrosolen. Cnidoscolus monicanus is characterized by the following combination of characters: tree with grayish non-exfoliating bark and verticillate branching, petioles with two discrete glands projecting outward from the epidermis, leaf laminas (16-) $20-41(-60) \times(25-)$ $36-67(-75) \mathrm{cm}$, leaf margins entire or with a few obscure to rarely caudate teeth, staminate flowers with a pubescent zone on the staminal column 3-4 mm long, pistillate flowers with a tomentulose perianth, a tomentose to sericeous ovary, peduncles of the pistillate infructescence $1.7-5 \mathrm{~cm}$ long, capsule with distal ribs and an acute apex, pedicels 5-20 mm long, and seeds 24-32 mm long. The new species occurs at elevations of $750-1640 \mathrm{~m}$ in tropical deciduous and semideciduous forest. We applied the Method for Evaluation of Risk Extinction for Wild Species in Mexico (MER) to estimate the conservation status of C. monicanus, and we concluded that it is threatened. We also evaluated the new species using applicable IUCN criteria and found it to be Endangered (EN).

Resumen. Se describe e ilustra Cnidoscolus monicanus J. A. Lomelí, Sahagún \& V. W. Steinmann (Euphorbiaceae), especie nueva para la ciencia endémica del occidente de México. La nueva especie pertenece a Cnidoscolus sección Calyptrosolen (Müller
Argoviensis ex Pax) Pax \& K. Hoffmann y está cercanamente relacionada con $C$. elasticus Lundell y con C. tepiquensis (Costantin \& Gallaud) McVaugh. Se proporciona una clave de identificación para las especies del complejo C. tepiquensis. Estas especies comparten el hábito arborescente poco o nada urticante en la madurez, las inflorescencias por lo general unisexuales y las grandes dimensiones de las semillas. Se hipotetiza que estos taxa forman un grupo monofilético dentro de la sección Calyptrosolen. Cnidoscolus monicanus se caracteriza por la combinación de los siguientes caracteres: árbol con corteza grisácea no exfoliante, ramificación verticilada, pecíolo con dos glándulas discretas, hoja con lámina de $(16-) 20-41(-60) \times(25-) 36-67(-75) \mathrm{cm}$, margen foliar entero o con pocos dientes obscuros a raramente caudados, flores estaminadas con zona pubescente de la columna estaminal de $3-4 \mathrm{~mm}$ de largo, flores pistiladas con perianto tomentuloso, ovario tomentoso a seríceo, pedúnculo de la infructescencia pistilada de $1.7-5 \mathrm{~cm}$ de largo, cápsula con costillas distales y ápice agudo, pedicelo de 5-20 mm de largo, semillas 24-32 mm de largo. Crece a altitudes de 750-1640 m en bosque tropical caducifolio y subcaducifolio. Se aplicó el Método de Evaluación del Riesgo de Extinción de las Especies Silvestres en México (MER) para estimar el estado de conservación de C. monicanus y se concluye que está amenazada. También se evaluó la nueva especie con los criterios aplicables de la UICN y se encontró que está En Peligro (EN).

Key words: Cnidoscolus, Euphorbiaceae, IUCN Red List, Jalisco, MER evaluation, Michoacán, western Mexico.

During the examination of unidentified material of Euphorbiaceae at the herbarium of the Instituto de Ecología-Centro Regional del Bajío (IEB), specimens 
of an interesting species of Cnidoscolus Pohl came to light. The same species was also independently collected by botanists at the Universidad Autónoma de Guadalajara during their explorations in the southwestern region of the Mexican state of Michoacán between 1998 and 2002. The material, after careful study, appears to belong to an undescribed species and is herein described as new to science. The new species is currently known from only two municipalities of Michoacán and from a location near Casimiro Castillo, in the adjacent state of Jalisco.

The genus Cnidoscolus is characterized by stinging epidermal hairs, glands on the distal part of the petiole, white pith, a single-whorled white perianth, and a style with three to five dichotomous branches ending in slender tips. In addition, the pistillate flowers develop rudimentary stamens and the staminate flowers have filiform sterile processes and a stipitate glandular disc that originates above the base of the staminal column (McVaugh, 1944).

Section Calyptrosolen (Müller Argoviensis ex Pax) Pax \& K. Hoffmann includes the species of Cnidoscolus with palmately lobed leaves, single or paired petiolar glands, monadelphous stamens in two verticils, and relatively floriferous cymes (McVaugh, 1944). This section comprises about 40 species and reaches its center of diversity in Mexico (Breckon, 1975). The objective of this study is to describe, illustrate, and estimate the conservation status of $C$. monicanus, a new species belonging to section Calyptrosolen.

\section{Material and Methods}

Four trips were made to southwestern Michoacán in western Mexico to collect material and to take photographs of the undescribed species. An additional trip was made to the mountains of southern Sinaloa to collect and study Cnidoscolus tepiquensis (Costantin \& Gallaud) McVaugh and C. elasticus Lundell, two apparently closely related species. Living plants of $C$. tepiquensis and C. monicanus are kept in cultivation in the "Jorge Victor Eller T." Botanical Garden at the Universidad Autónoma de Guadalajara, and these were used to make the observations that support this study and to prepare the identification keys included below. Data from herbarium specimens housed at GUADA, IBUG, and IEB were also used. The Vascular Plant Types Catalog of the New York Botanical Garden, available at <http://sciweb.nybg. org/Science2/hcol/vasc/index.asp $>$, provided important information. Terminology and limits of plant structure measurements follow the criteria of Breckon (1975). Measurement ranges in Table 1 for $C$. elasticus and C. tepiquensis were partly based on the descriptions of Breckon (1975). To estimate the conservation status of $C$. monicanus, we used the Method for Evaluation of Extinction Risk for Wild Species in Mexico (MER) (SEMARNAT, 2002; Olson et al., 2005) and the criteria of the International Union for Conservation of Nature and Natural Resources (IUCN, 2001). MER evaluations are required by law in Mexico for native species to receive legal protection.

Cnidoscolus monicanus J. A. Lomelí, Sahagún \& V. W. Steinmann, sp. nov. TYPE: Mexico. Michoacán: Mun. Chinicuila, Rancho El Tejón, on Aquila-Coalcomán hwy., 1640 m, 7 June 2002 (o fl.), E. Sahagún 2396 with J. A. Lomeli \& S. Parra (holotype, GUADA; isotypes, IEB, MEXU, MO). Figure 1.

Arbor $7-20 \mathrm{~m}$ alta, maturitate quasi tote inermis, trunci cortice griseo vel ferrugineo non exfoliato, ramificatione verticillata, ramulis monomorphis medulla farcta. Folium petiolo glandibus geminatis discretis praedito; lamina (16-) $20-41(-60) \times(25-) 36-67(-75) \mathrm{cm}$ lata, margine integro vel dentibus paucis obscuris vel raro caudatis munito. Flos masculus columnae staminalis zona pubescente $3-4 \mathrm{~mm}$ longa; flos femineus perianthio adaxialiter tomentuloso, ovario tomentoso usque sericeo. Infructescentia feminea pedunculo $1.7-5 \mathrm{~cm}$ longo insidens, pedicellis $5-20 \mathrm{~mm}$ longis. Capsula distaliter costata et apice acuta; seminibus 24-32 mm longis.

Drought deciduous tree 7-20 m tall, trunk ca. 30 $50 \mathrm{~cm}$ DBH, urticating when young, virtually unarmed at maturity; bark light gray to light brown or reddish, non-exfoliating, slightly fissured with vertical, light-colored, spindle-shaped fissures and round ferruginous lenticels; latex white, copious; stem erect, monomorphic, with verticillate branching; current year branchlets 11-23 mm thick, fleshy, lustrous, glabrous, dark green with straw-colored lenticels; second year branchlets gray to brown, non-exfoliating, the pith solid even after drying. Young leaves with petiole tomentose to tomentulose; lamina yellowish green, depressed, palmatisect, with 5 to 7 lanceolate to elliptic lobes; margin entire, apex long caudate, tomentose on adaxial surface, the tomentum light brown, obscuring the veins and the epidermis, abaxial surface tomentulose, especially on the sides of the veins; mature leaves with stipules caducous, $4-8 \mathrm{~mm}$, deltoid, green, abaxial surface glabrous, papillateglandular with ca. 12 to 22 white glands, the apex acuminate, 2-3 mm, petiole terete, (14-)22-55 cm $\times$ $7-10 \mathrm{~mm}$ thick in fresh material, glabrous except sometimes for a longitudinal line of acicular slightly stinging trichomes on the adaxial surface, glands 2 , discrete, projecting outward from the epidermis, cushion-like, 1-2 mm; lamina palmately parted to 
Table 1. Principal differences between Cnidoscolus monicanus and closely related species.

\begin{tabular}{|c|c|c|c|}
\hline Character & C. elasticus & C. monicanus & C. tepiquensis \\
\hline Elevation (m) & $(500-) 900-1600$ & $750-1640$ & $30-900$ \\
\hline Branching & non-verticillate & verticillate & verticillate \\
\hline Trunk bark & exfoliating, reddish & $\begin{array}{l}\text { non-exfoliating, grayish to } \\
\text { reddish }\end{array}$ & non-exfoliating, grayish \\
\hline Stipules, abaxial surface & tomentose & glabrous & tomentose \\
\hline Glands & $\begin{array}{l}\text { 2, discrete, projecting } \\
\text { outward from the } \\
\text { epidermis, cushion-like }\end{array}$ & $\begin{array}{l}2 \text {, discrete, projecting } \\
\text { outward from the } \\
\text { epidermis, cushion-like }\end{array}$ & $\begin{array}{l}\text { 1, U-shaped, flush with the } \\
\text { epidermis }\end{array}$ \\
\hline Lamina, length $(\mathrm{cm})$ & 15 & $(16-) 20-41(-60)$ & (15-)19-49 \\
\hline Lamina, width $(\mathrm{cm})$ & 25 & $(25-) 36-67(-75)$ & $(18-) 24-56$ \\
\hline Lamina, primary veins & 5 or 7 & 7 or 9 & 7 or 9 \\
\hline Lamina, marginal teeth* & $\begin{array}{l}0 \text { to } 9(26), \text { obscure to } \\
\text { rarely short caudate }\end{array}$ & $\begin{array}{l}0 \text { to } 3(6) \text {, obscure to rarely } \\
\text { caudate }\end{array}$ & 20 to 28 , caudate \\
\hline Staminate flower bud & strongly pyriform & $\begin{array}{l}\text { conspicuously swollen about } \\
\text { the disc, narrow-clavate } \\
\text { above }\end{array}$ & $\begin{array}{l}\text { conspicuously swollen about } \\
\text { the disc, narrow-clavate } \\
\text { above }\end{array}$ \\
\hline $\begin{array}{l}\text { Staminate flower. Pedicel length } \\
\text { after abscission (mm) }\end{array}$ & $<0.5$ & $>1.5$ & $\leq 1$ \\
\hline $\begin{array}{l}\text { Staminate flower. Length of } \\
\text { pubescent zone (mm) }\end{array}$ & $(1.5-) 3.5-3.8$ & $3-4$ & $1-2$ \\
\hline Pistillate perianth indumentum & $\begin{array}{l}\text { tomentose, with few } \\
\text { stinging hairs }\end{array}$ & tomentulose, not stinging & glabrous \\
\hline Ovary, length (mm) & $3-6$ & $5-7.5$ & $3.5-4$ \\
\hline Ovary indumentum & sericeous & tomentose to sericeous & $\begin{array}{l}\text { glabrous or with few } \\
\text { adpressed hairs at base }\end{array}$ \\
\hline $\begin{array}{l}\text { Infructescence, length of } \\
\text { peduncle }(\mathrm{cm})\end{array}$ & $5-13$ & $1.7-5$ & $20.5-23.5$ \\
\hline Capsule, length of pedicel (mm) & $0-1.3$ & $5-20$ & $6-40$ \\
\hline Capsule, apex at maturity & acute & acute & rounded \\
\hline Pericarp & without ribs & with ribs & without ribs \\
\hline Columella, length (mm) & 23 & $30-35$ & $27-29$ \\
\hline Seeds, length (mm) & $17-23$ & $24-32$ & $22-27$ \\
\hline
\end{tabular}

* The primary veins extending at the apices of the lobes were not considered in the count.

palmatisect, with 5 to 7 lobes and 7 to 9 primary yellowish palmate veins, (16-)20-41(-60) $\times(25-) 36-$ $67(-75) \mathrm{cm}$, the lobes caudate at the apex, the apical lobe spatulate to obovate, $15-24 \mathrm{~cm}$ long, $2.8-7.2 \mathrm{~cm}$ wide at base, and $7-13 \mathrm{~cm}$ wide at the widest point, the apex $2.6-4 \mathrm{~cm}$, distal lateral lobes spatulate to obovate, $16-25 \times 6.5-7 \mathrm{~cm}$, proximal lateral lobes obovate to oblanceolate, $12-20 \mathrm{~cm}$, base cordate, glabrous or with a few stinging hairs, the basal sinus $3-3.5 \mathrm{~cm}$ deep, margin entire except for 0 to $3(6)$ obscure to rarely caudate teeth distributed among the lobes, adaxial leaf surface hirtellous, slightly stinging, abaxial leaf surface hirsute. Dichasial cymes 2 to 4 , subapical, commonly unisexual, only staminate in juvenile treelets, staminate, pistillate, or mixed in adult trees; staminate inflorescences multiflorous, up to $5 \times$ dichotomous and with a ringed scar between each dichotomy, the scar made from the early abortive immature pistillate flowers; pistillate inflorescences usually with a single dichotomy, pauciflorous (with 2 to 6 flowers), appearing umbellate; mixed inflorescences with 4 to 6 dichotomous branches, the pistillate flowers solitary at the base of proximal dichotomies and the staminate flowers in the distal dichotomies, 30 to 96 per inflorescence; in all cases the peduncle $2.2-8 \mathrm{~cm}$, tomentose to tomentulose to glabrescent, the tomentum brown to dull white; bracts 3-8 mm, lanceolate, with a small basal lobe on each side, tomentose on both surfaces; perianth of the staminate flowers white, adaxial surface glabrous, abaxial surface tomentulose, not stinging, clavate in bud, swollen around the disc, salverform, 11.4$14 \mathrm{~mm}$; perianth tube $8-11 \mathrm{~mm}$, lobes $6-8 \times 3$ $5 \mathrm{~mm}$ in fresh material, elliptic to oblong, reflexed; stamens 10, glabrous, filaments of the upper whorl 11-13.5 mm, those of the lower verticil ca. 8-9 mm, anthers dorsifixed, $2.5-3.3 \mathrm{~mm}$, those of the upper whorl completely exserted, those of the lower whorl partially exserted, the pubescent zone of the staminal column 3-4 mm long with yellowish white indumentum ca. $1 \mathrm{~mm}$, stipitate glandular disc (0.5-)1.1$1.2 \mathrm{~mm}$, orange when fresh, stipe ca. $0.3 \mathrm{~mm}$, staminal column $8-9.5 \mathrm{~mm}$, apex with a pistillode represented by 3 sterile processes somewhat longer than $2 \mathrm{~mm}$; perianth of the pistillate flowers white, adaxial surface glabrous, abaxial surface tomentulose, 

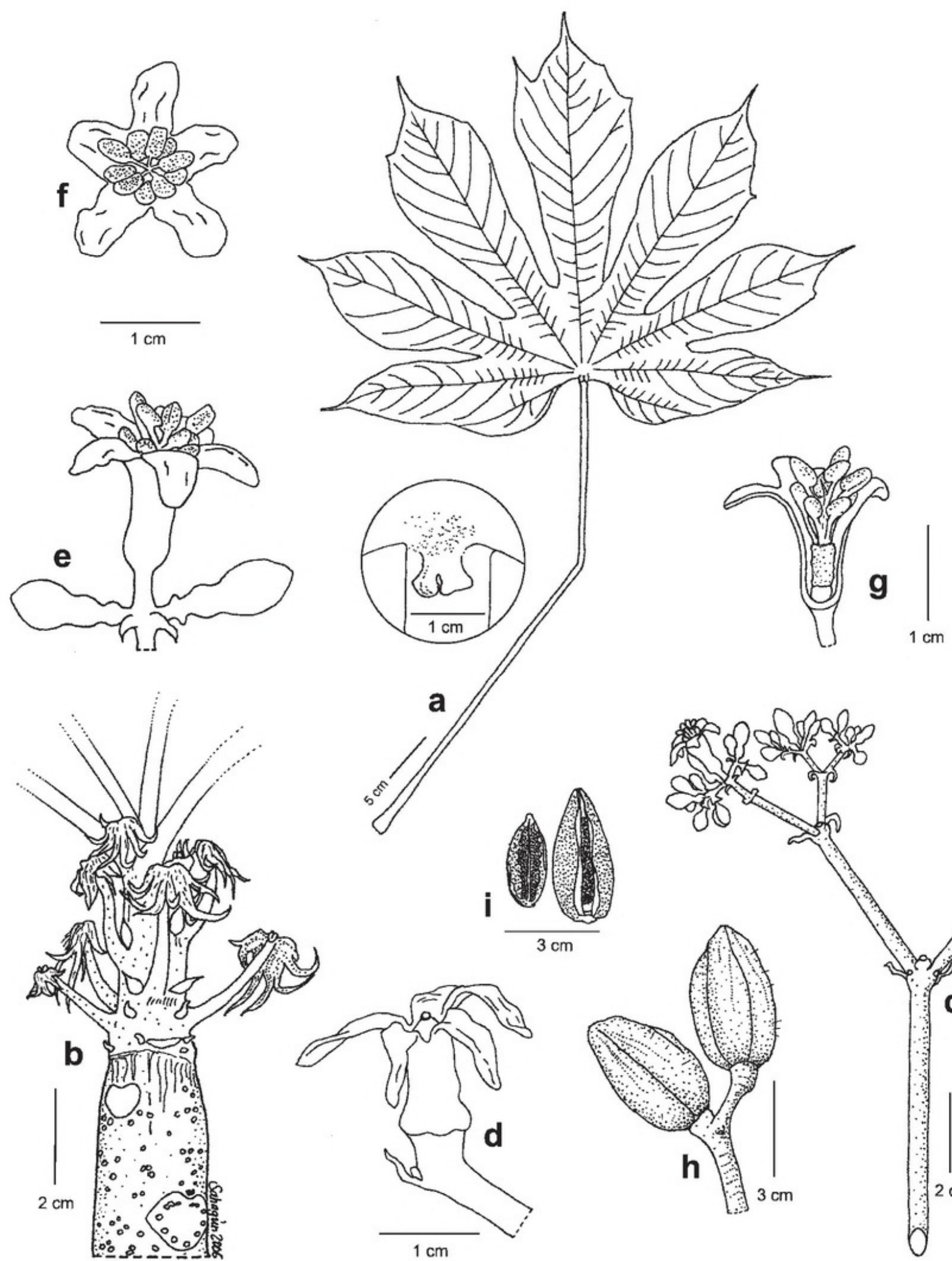

b
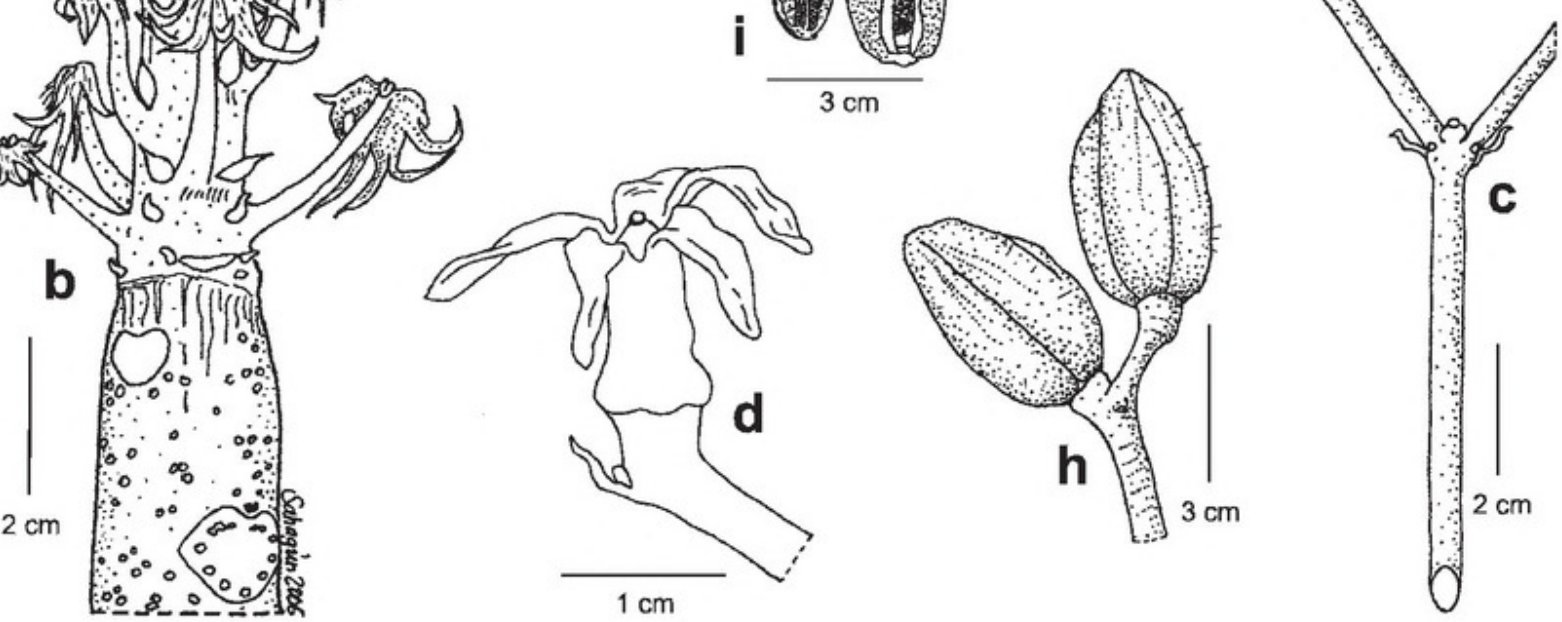

Figure 1. Cnidoscolus monicanus J. A. Lomelí, Sahagún \& V. W. Steinmann. -A. Leaf showing adaxial surface; inset shows a detail of the petiolar glands. - B. Apex of a sprouting stem showing lenticels, foliar scars, stipules, young leaves, and four peduncles of staminate cymes. - C. Staminate cyme with bracts, flower buds, and one staminate flower at anthesis. -D. Senescent pistillate flower in lateral view showing one bract and the robust pedicel; note the ovary apex with deciduous stigma. -E. Apical section of the staminate inflorescence showing bracts, two flower buds, and one staminate flower in lateral view; note the scale bar above applies to both staminate flowers. - F. Staminate flower viewed from above. - G. Staminate flower in longitudinal section showing in ascending order the pedicel, sectioned single-whorled perianth, glandular disc, pubescent zone of staminal column, and stamens. - H. Nearly mature infructescence in lateral view (note the short peduncle). - I. Seed in dorsal view (left); dry mature dehiscent capsule showing a seed inside (right). A-C, E-G, from a plant cultivated at the Botanic Garden of Universidad Autónoma de Guadalajara (JVET 2234); D, from the holotype, Sahagún 2396 with Lomelí \& Parra (GUADA); H, I, from Sahagún 2544 (GUADA). 
not stinging, salverform, 17-18 mm, perianth tube 6$9 \mathrm{~mm}$, subcylindrical, gradually narrower toward the throat, proximal diameter 5.5-6 mm, distal diameter $3.5-4 \mathrm{~mm}$, lobes $6-10 \times 2-3 \mathrm{~mm}$; ovary pyriform to ellipsoid, $5-7.5 \times 2.5-3.5 \mathrm{~mm}$, sulcate or costate, tomentose to sericeous, styles 3 , glabrous, $4 \mathrm{~mm}$ long, bifid for $1-1.5 \mathrm{~mm}$, disc height $0.5-1 \mathrm{~mm}$, tomentose or hirtellous, green when fresh, brown in pressed material; infructescence with a peduncle $1.7-5 \mathrm{~cm} \times$ 2-4.5 mm thick, tomentose to tomentulose, the tomentum brown, pedicels glabrescent, 5-20 $\times 3-$ $5 \mathrm{~mm}$ thick; capsule loculicidal, ovoid, 3-4.5 $\times 1.4-$ $2 \mathrm{~cm}$, the apex rostrate when young and acute at maturity, rostrum 1-3 mm, soon caducous; pericarp green when fresh or dark brown to nearly black in herbarium specimens, hispid, with stinging trichomes ca. $2 \mathrm{~mm}$ and 3 ribs to $3 \mathrm{~cm}$ on the distal part of each carpel, the lateral ribs longer than the central one, dehiscence lines light colored; columella $3-3.5 \mathrm{~cm}$; seeds elliptic in outline, $2.4-3.2 \mathrm{~cm}$ long, $1-1.2 \mathrm{~cm}$ wide, 6-7 mm thick, base rounded, apex acute, rostrate, the rostrum $1.5-2 \mathrm{~mm}$; the ventral side straight to shallowly concave, uniformly dark brown or light brown grained with dark brown, with a light brown stripe on the margin and a central longitudinal furrow, the dorsal side light brown grained with dark brown, with a longitudinal central costa.

Habitat and distribution. In Michoacán, the new species occurs in tropical deciduous forest (sensu Rzedowski, 1983) near the ecotone with oak-pine forest, at an elevation of 1430-1640 m with Agave gypsophila Gentry, Bursera Jacquin ex L., Clusia salvinii Donnell Smith, Ficus L., Lysiloma acapulcense (Kunth) Bentham, and Neobuxbaumia Backeberg. In Jalisco, it thrives in tropical semideciduous forest at an elevation of $750-900 \mathrm{~m}$ with Hura polyandra Baillon, Ceiba Miller, Ficus, Brosimum alicastrum Swartz, and Euphorbia tanquahuete Sessé \& Mociño.

Apparently endemic to the Sierra Madre del Sur in western Mexico, it is currently known from southwestern Michoacán, in the municipalities of Chinicuila and Coalcomán. It also occurs in Casimiro Castillo, in the Sierra de Manantlán, southern Jalisco.

Conservation status. Conservation status of the new species was assessed using the Method for Evaluation of Extinction Risk for Wild Species in Mexico (MER) (SEMARNAT, 2002). The criteria were assessed as follows:

Criterion A: extent of the distribution of the taxon in Mexico. The territorial extension of Mexico totals about 1,964,375 km² (SEP, 1996; INEGI, 2005), while Cnidoscolus monicanus is only known from three locations in the municipalities of Chinicuila and Coalcomán, in Michoacán, and from one location in the municipality of Casimiro Castillo, in Jalisco, which together add up to $4873.13 \mathrm{~km}^{2}$ (INEGI, 1986), or $0.25 \%$ of the territory of Mexico. This is considerably less than the $5 \%$ of the Mexican territory set as a limit by this criterion; thus, the distribution of C. monicanus is considered as "very restricted," which corresponds to a score of 4 .

Criterion B: status of the habitat regarding the natural development of the taxon. Cnidoscolus monicanus grows in tropical deciduous or semideciduous forest on soils that range from shallow-rocky to relatively deep, usually with abundant calcareous rocks, conditions that are common in southwestern Michoacán, Colima, and southern Jalisco, which led us to consider the habitat as favorable or less limiting and to assign this criterion a score of 1 .

Criterion C: intrinsic biological vulnerability of the taxon. This species is noteworthy for its tendency to produce unisexual trees, a trait that requires the simultaneous presence of flowers of both sexes in the vicinity for pollination to take place. Also, we observed few juveniles of about one or two years old but did not observe recently germinated seedlings; this suggests that the rate of recruitment in this species is low, which is confirmed by the small number of populations with few individuals known. We also observed that only fully grown trees produced pistillate flowers and seeds, while younger treelets produced only staminate flowers. Thus, we observed few mature trees in fruit. This has obvious reproductive implications, making this species vulnerable. Furthermore, Cnidoscolus monicanus produces the largest seeds in section Calyptrosolen, which apparently limits their dispersal unless a vector is involved. We also observed partly eaten seeds among rocks near parent trees, which suggests predation by mammals, as birds normally would eat the seeds whole; this may also have some potential for dispersal. In addition, unlike other species of Cnidoscolus, the capsules of $C$. monicanus apparently lack explosive dehiscence, and consequently the seeds fall near the parent plant. We consider that these factors limit the dispersal and reproductive potential of this species and make it vulnerable. The fact that some recruitment is occurring despite the arguments discussed above leads us to consider the vulnerability of this species as intermediate and to assign this criterion a score of 2 .

Criterion D: impact of human activities on the taxon. In the locations where this species is known to occur, the native vegetation is cut to grow corn or to induce grasslands as pasture for cattle, which leads to habitat loss and poses a risk to this and other species in those areas. However, a few trees were observed growing on very rocky ground that was unsuitable for 
human use. Furthermore, the Jalisco population occurs within the Manantlán Biosphere Reserve, which affords it protection. We concluded that impact of human activities is intermediate and assigned this criterion a score of 3 .

To evaluate the status of a species, the scores of the various criteria are summed. Species with total scores between 12 and 14 are considered in danger of extinction, those with a score of 10 or 11 are threatened, and those with scores of 9 or below are considered to be at little current risk. The sum of the scores of all criteria totaled 10, thus Cnidoscolus monicanus is considered threatened.

We also evaluated the conservation status of Cnidoscolus monicanus using the applicable criteria of the International Union for the Conservation of Nature and Natural Resources (IUCN, 2001). The distribution as presently known is severely fragmented. Only four confirmed localities are known to exist. In all of them, except in the Manantlán Biosphere Reserve, habitat loss is creating pressure on existing populations. With the information currently at hand, we estimated the total population size to be fewer than 2500 mature individuals. Due to the limited use of the new species by rural people, a continuing decline in the populations due to land-use change is observed. However, this is not the case in the Manantlan Biosphere Reserve, which is estimated to contain the majority of mature individuals. The Michoacán populations have only a handful of mature trees. The new species may very likely also occur in Nayarit, but we do not have any confirmed collections or population size estimates from that state. Based on the analysis of IUCN Red List criteria given here, we conclude that $C$. monicanus is Endangered (EN).

Phenology. Foliage is present from mid-June to October, with flowering from April to June, and fruiting from September to October.

Etymology. The specific epithet honors Mónica Edith Lomelí-Zavala, a young student of biology and daughter of the senior author.

Common name. Chicle (Nicanor Mendoza, 2001, pers. comm.).

Potential use and economic value. Although no actual uses were observed in the sites where Cnidoscolus monicanus was recorded, the species produces abundant white latex, which has potential as a source of natural rubber. The latex of the closely related $C$. tepiquensis is used in Talpa de Allende, in western Jalisco, and in Huajicori, Acaponeta, in northern Nayarit, to produce colorful art crafts. The seeds are reportedly edible either raw or roasted, and are known as "cucarachos" as they resemble cockroaches.
Discussion. Cnidoscolus monicanus is closely related to C. elasticus and C. tepiquensis, with which it shares an arborescent, nearly unarmed habit at maturity, solid pith, similar pistillate perianth length, and large fruits and seeds. Based on these characteristics, we hypothesize that the three species comprise a monophyletic group in section Calyptrosolen. All three species of this complex produce abundant latex, which according to Williams (1962, for C. elasticus and C. tepiquensis) contains a high percentage of hydrocarbons and resin. In addition, the plants in this group have a tendency to produce unisexual cymes. They are restricted to the Pacific slope of western Mexico, and the species are allopatrically distributed north to south as follows: C. elasticus, C. tepiquensis, and $C$. monicanus. Although the southern distribution limit of C. elasticus seems to overlap slightly with the northern distribution limit of C. tepiquensis in southern Sinaloa, the taxa are separated by elevation, with the former restricted to the highlands in the mountains and the latter found at low elevations. Similarly, altitudinal differences farther south also separate $C$. tepiquensis and $C$. monicanus, with the latter occurring at higher elevations than the former. Although the elevation ranges shown in Table 1 overlap slightly, there is no evidence that any of the species grow sympatrically. Because of the absence of herbarium specimens and his inability to find $C$. tepiquensis in the municipality of Concordia, in Sinaloa, Breckon (1975) questioned Lundell's (1945) assertion that this municipality is the northern limit of this species. However, we collected C. tepiquensis near Cacalotán $\left(23^{\circ} 04^{\prime} 28^{\prime \prime} \mathrm{N}, 105^{\circ} 51^{\prime} 17^{\prime \prime} \mathrm{W}\right)$, growing at an elevation of $50 \mathrm{~m}$ in the municipality of Rosario, which is adjacent to Concordia (J. A. Lomeli-Sención 3658 with E. Ramírez M. \& G. E. Lomelí Z., GUADA). This finding supports Lundell's distributional limit indicated above.

This new taxon is closely related to Cnidoscolus elasticus, with which it shares two discrete petiolar glands, few, obscure marginal teeth in the leaf lamina that are only rarely caudate, staminate flowers with a long pubescent zone (usually $3-4 \mathrm{~mm}$ ) on the staminal column, pistillate flowers with an abaxially pubescent perianth, a pubescent ovary, short peduncles of the infructescence, capsules that are acute at maturity, and a habitat at higher elevations. However, $C$. monicanus differs from C. elasticus in its grayish non-exfoliating bark, verticillate branching, glabrous stipules, longer capsule pedicels, and larger leaf lamina, fruits, and seeds (Table 1).

Cnidoscolus monicanus is also related to $C$. tepiquensis, with which it shares verticillate branching, grayish to light brown non-exfoliating bark, large leaf laminas with seven or nine primary palmate veins, 
similar staminate flower bud shape, longer capsule pedicels, and longer columellas and seeds. However, C. monicanus is distinguished from C. tepiquensis by its glabrous stipules, petioles with two discrete glands, leaf margins that are entire or with few obscure to rarely caudate teeth, staminate flowers with a longer pubescent zone on the staminal column, pistillate flowers with a tomentulose perianth, longer tomentose to sericeous ovaries, shorter peduncles of the pistillate infructescences, capsules with distal ribs and acute apex, and a habitat at a higher elevation (Table 1). These two species' contrasting adaptations to climate, brought about by the varying elevation, is very evident in the plants cultivated at "Jorge Victor Eller T." Botanical Garden, which is located at an elevation of $1700 \mathrm{~m}$ and has a mean annual temperature of $23.3^{\circ} \mathrm{C}$. These conditions are similar to those found in the habitat of $C$. monicanus but have been stressfully cold for $C$. tepiquensis, which has grown slowly in 15 years of cultivation. Contrastingly, C. monicanus has grown vigorously, reached the same height as C. tepiquensis, and attained a thicker trunk in nine years of cultivation.

Breckon's (1975) concept of Cnidoscolus tepiquensis includes what we describe here as $C$. monicanus. This conclusion is based on his description of the species and on his identification of a specimen (McVaugh 19850, MICH) as C. tepiquensis, a duplicate of which (IEB) we identify as $C$. monicanus. Furthermore, in the illustration he presents for C. tepiquensis (Breckon, 1975: pl. 30a), the leaf is more typical of $C$. monicanus. Unfortunately, we were unable to see the specimen on which the drawing is based (Breckon \& Breckon 1378 [DAVD and cannot confirm our determination based on the illustration. A typical leaf of $C$. tepiquensis may be seen in Williams (1962: fig. 11).

It is presently unclear which species of the complex is more closely related to Cnidoscolus monicanus. Although our key shows $C$. monicanus and $C$. elasticus together in couplet 2 , that does not indicate a closer affinity. The key is artificial and was built using the most distinctive characters available. A cladistic study is needed to clarify the affinities within the complex.

Key to the Species of the Cnidoscolus tepiquensis Complex IN Mexico

la. Leaves rarely with 0 to $3(6)$ caudate teeth similar to the caudate lobe apices; petiolar glands 2, discrete, projecting outward from the epidermis, cushionlike; ovary tomentose to sericeous; fruiting peduncle $\leq 13 \mathrm{~cm}$ long; staminate flowers with the pubescent zone of the staminal column $\geq 3 \mathrm{~mm}$ long; capsule with apex acute at maturity.

2a. Trunk bark non-exfoliating, gray or reddish brown; branching verticillate; mature leaves glabrescent, $16-60 \times 25-75 \mathrm{~cm}$, stipules glabrous; pedicel of staminate flower $>1.5 \mathrm{~mm}$ long after abscission, capsule pedicel 5-20 mm long; pericarp ribbed; columella 30-35 mm long; seeds 24-32 mm long $\ldots \ldots \ldots \ldots \ldots \ldots . \ldots \ldots$. monicanus

2b. Trunk bark exfoliating, reddish brown; branching not verticillate; mature leaves tomentose, smaller, to $15 \times 25 \mathrm{~cm}$, stipules tomentose; pedicel of staminate flower $<0.5 \mathrm{~mm}$ long after abscission; capsule pedicel 0-1.3 mm long; pericarp not ribbed; columellaca. $23 \mathrm{~mm}$ long; seeds $17-23 \mathrm{~mm}$ long . . . . . . . . . . . . . . . . .

1b. Leaves with 20 to 28 caudate teeth similar to the caudate lobe apices; petiolar gland 1, U-shaped, flush with the epidermis, not cushion-like; ovary glabrous; fruiting peduncle $\geq 20 \mathrm{~cm}$ long; staminate flowers with the pubescent zone of the staminal column $<2.5 \mathrm{~mm}$ long; capsule with apex rounded at maturity ......... C. tepiquensis

Paratypes. MEXICO. Jalisco: Mun. Casimiro Castillo, tropical forest in barranca $16 \mathrm{mi}$. SW of Autlán (seaward slopes $6.5 \mathrm{mi}$. below hwy. pass), $750 \mathrm{~m}, 4$ Oct. 1960 (fr.), $R$. McVaugh 19850 with C. Feddema \& R. W. Pippen (IEB). Michoacán: Mun. Chinicuila, near Tehuantepec on hwy. Aquila-Coalcomán, 9 June 2001 (fl.), E. Sahagún 2306 \& J. A. Lomeli (GUADA), 4 Oct. 2002 (fr.), E. Sahagún 2544 with J. A. Lomeli \& P. Carrillo (GUADA); 22 Apr. 2005 (fl.), material obtained from previous locality cultivated at the JVET Botanic Garden, Universidad Autón. Guadalajara, J. A. Lomeli 3796 with E. Sahagún \& S. Parra (GUADA); Mun. Coalcomán, La Yerbabuena del Naranjillo, cañada del Colorín, 28 Apr. 1990 (fl.), H. Díaz-Barriga \& E. PérezCálix s.n. (IEB).

Acknowledgments. The authors thank Nicanor Mendoza and his family and Modesto Ramos-Castañeda for their hospitality and valuable companionship during field explorations in Michoacán and the Sierra in southern Sinaloa, respectively. Jorge L. CrespoDurán also provided useful information and hospitality at Rosario, Sinaloa. We also thank two anonymous reviewers and Paul Berry for their valuable comments to the manuscript. We are especially indebted to Universidad Autónoma de Guadalajara, Idea Wild Foundation, and Houston Cactus and Succulent Society for economic and logistic support and to the New York Botanical Garden for making type specimens available online.

\section{Literature Cited}

Breckon, G. J. 1975. Cnidoscolus, section Calyptrosolen (Euphorbiaceae) in Mexico and Central America. Ph.D. Thesis, University of California, Davis.

INEGI (Instituto Nacional de Estadística Geografía e Informática). 1986. Michoacán en Síntesis. Secretaría de Programación y Presupuesto, México, D.F.

2005. Superficie continental e insular del territorio nacional. México. Available at: <http://mapserver.inegi. gob.mx/geografia/espanol/datosgeogra/extterri/frontera.cfm? $c=154>$, accessed 2 December 2008. 
IUCN. 2001. IUCN Red List Categories and Criteria, Version 3.1. Prepared by the IUCN Species Survival Commission. IUCN, Gland, Switzerland, and Cambridge, United Kingdom.

Lundell, C. L. 1945. The genus Cnidoscolus in Mexico: New species and critical notes. Bull. Torrey Bot. Club 72: 319-334.

McVaugh, R. 1944. The genus Cnidoscolus: Generic limits and intrageneric groups. Bull. Torrey Bot. Club 71: 457-474.

Olson, M. E., J. A. Lomelí-Sención \& N. I. Cacho. 2005. Extinction threat in the Pedilanthus clade (Euphorbia, Euphorbiaceae), with special reference to the recently rediscovered E. conzattii ( $P$. pulchellus). Amer. J. Bot. 92(4): 634-641.
Rzedowski, J. 1983. Vegetación de México. 2 reimpresión. Limusa, México, D.F.

SEMARNAT (Secretaría del Medio Ambiente y Recursos Naturales). 2002. Norma oficial mexicana NOM-059ECOL-2001. Protección ambiental. Especies nativas de México de flora y fauna silvestres. Categorías de riesgo y especificaciones para su inclusión, exclusión o cambio. Lista de especies en riesgo. Anexo normativo I, método de evaluación del riesgo de extinción de las especies silvestres en México (MER). Diario Oficial de la Federación.

SEP (Secretaría de Educación Pública). 1996. Atlas de México. Educación Primaria. SEP, México, D.F.

Williams, L. 1962. Laticiferous plants of economic importance II. Mexican chilte (Cnidoscolus): A source of guttalike material. Econ. Bot. 16(68): 53-70. 


\section{$2 \mathrm{BHL}$ Biodiversity Heritage Library}

Lomelí-Sención, José Aquileo, Sahagún-Godínez, Eduardo, and Steinmann, Victor W. 2009. "Cnidoscolus Monicanus (euphorbiaceae), An Endemic New Species Of Laticiferous, Non-Stinging Spurge Nettle From Western Mexico." Novon a journal of botanical nomenclature from the Missouri Botanical Garden $19,68-75$.

View This Item Online: https://www.biodiversitylibrary.org/item/124658

Permalink: https://www.biodiversitylibrary.org/partpdf/121880

\section{Holding Institution}

Missouri Botanical Garden, Peter H. Raven Library

\section{Sponsored by}

Missouri Botanical Garden

\section{Copyright \& Reuse}

Copyright Status: Permission to digitize granted by rights holder Rights: https://www.biodiversitylibrary.org/permissions

This document was created from content at the Biodiversity Heritage Library, the world's largest open access digital library for biodiversity literature and archives. Visit BHL at https://www.biodiversitylibrary.org. 